\title{
Zaman, Mekân, Beden ve Öznelerarası Düzlemde Sanatçının Bir Genç Adam Olarak Korkusu $^{1}$
}

Hakan YILMAZ ${ }^{2}$

$\ddot{O} z$

Duygular üzerine yapılan birçok çalışmada, araştırmacılar bazı temel duyguların var olduğu savını ortaya atmıştır. Bu temel duyguların sayısı en az dört olarak belirlenmiştir ve bunlar mutluluk, kızgınlık, üzüntü ve korkudur. Diğer tüm duygular, bu dört ana duygu üzerine kuruludur. Bu çalışmada, fenomenolojik çerçeve kullanılarak, öncelikle öznenin varoluşunun bir parçası olan zaman, mekân, beden ve öznelerarası boyutlar tartışılacak, ardından korku duygusunun bu dört düzlemde nasıl deneyimlendiği ve hissedildiği incelenecektir. Ayrıca, bu düzlemlerin, korku duygusunun oluşumunda ne tür bir role sahip olduğu ve korkunun hissedilmesi esnasında bu düzlemlerin korku duygusuna kapılan birey tarafından deneyimlenmesinde hangi değişimlere uğradığ James Joyce'un Sanatçının Bir Genç Adam Olarak Portresi adlı romanında Stephen'ın yaşadığı iki olay üzerinden tartışılacaktır.

\section{Anahtar Sözcükler}

James Joyce

Sanatçının Bir Genç Adam

Olarak Portresi

korku

zaman

mekân

öznelerarasılık

Makale Hakkında

Geliş Tarihi: 13.01.2021

Kabul Tarihi: 14.04.2021

Doi:

10.20304/humanitas.860025

\section{Fear of the Artist as a Young Man in Time, Space, Body and Intersubjective Dimensions} \begin{abstract}
In most studies on emotions, researchers have proposed that there are some primary emotions. The number of these basic emotions is said to be at least four and they include happiness, anger, sadness, and fear. All other emotions build on these four primary emotions. In this study, first, by employing a phenomenological framework, time, space, body, and intersubjective dimensions which are part and parcel of the self's existence will be discussed, and then how the emotion of fear is experienced and felt in these four dimensions will be analyzed. Furthermore, what role these dimensions have in the formation of fear and what changes they undergo during the experience of fear will be examined with reference to two incidents that befall Stephen in James Joyce's A Portrait of the Artist as a Young Man.
\end{abstract}

Keywords

James Joyce

A Portrait of the Artist as a Young Man

fear

time

space

intersubjectivity

\section{About Article}

Received: 13.01.2021

Accepted: 14.04.2021

Doi:

10.20304/humanitas.860025

\footnotetext{
$1 \mathrm{Bu}$ çalışma, 4-6 Aralık 2019 tarihleri arasında Hacettepe Üniversitesi’nde düzenlenen "Korku Sempozyumu"nda sunduğum "İngiliz Modernist Yazınında Korkunun Anatomisi: Zaman, Mekân, Beden ve Öznelerarası Düzlemde Korku” başlıklı bildiriden türetilmiştir.

${ }^{2}$ Dr. Öğr. Üyesi, Burdur Mehmet Akif Ersoy Üniversitesi, Batı Dilleri ve Edebiyatları Bölümü, Burdur/Türkiye, hknylmzz@gmail.com, ORCID: 0000-0002-6019-2214
} 


\section{Giriș}

Duygular birçok farklı disiplin 1şığında değişik açılardan ele alınmış olduğundan, tam tanımlarını önermek pek mümkün görünmemektedir. Biyolojik açıdan, duygular, vücut sistemlerinde (otonom sinir sistemi (OSS), kas-iskelet sistemi, endokrin sistemi, peptit nörotransmitter ve nöroaktif peptit sistemleri, vb.) gerçekleşen değişimler olarak kategorize edilir (Turner, 2007, s. 2). Öte yandan, bilişsel yaklaşımlarda, duygular bireyin bulunduğu çevrede olgular, uyarıcılar ve olaylar karşısında yaptığı bilişsel değerlendirme sonucu hissettiği, deneyimlediği ve tanımlayabildiği duyguları kapsamaktadır (Plutchik, 1980, s. 910). Kültürel yaklaşımlar ve tanımlamalarda, duygular belli başlı fizyolojik uyarılmalara atfettiğimiz kelimeler ve tanımlamalar olarak karşımıza çıkmaktadır (Turner, 2007, s. 2). Sosyolojik açıdan bakıldığında, "duygu[nun] genellikle bedenin çevresel şartlara verdiği tepkiyle ilintili" olduğunu belirten Robert A. Thamm, bunun genişletilmesi gerektiğini ileri sürer ve duyguların sadece bizim sosyal durumlara verdiğimiz tepkiyle değil aynı zamanda bu sosyal durumların (örneğin sosyal bir ilişkide değişiklik ve bu ilişkinin farklı bir yön alması gibi durumların) değerlendirilmesi sonucu verdiğimiz "fizyolojik tepkiler (duygusal uyarılma)" olarak açıklanması gerektiğini söyler (Thamm, 2006, s. 16). Psikoloji alanında ise, duygular, "bir bireyin, kişisel olarak önemli olan bir olgu veya olay ile başa çıkmaya çalıştı̆ğ, deneyimsel, davranışsal ve fizyolojik unsurlar içeren kompleks bir tepki örüntüsüdür” ("Emotion,” t.b.). Bir başka deyişle, söz konusu alanda, duygular, düşünceyi ve davranışı etkileyen fiziksel ve psikolojik değişimleri meydana getiren bir duygu durumu olarak değerlendirilir.

Görüldügü üzere, oldukça farklı ama aynı zamanda birbiriyle ilintili tanımlamaları ve kavramsallaştırmaları barındıran duyguların ne olduğu ve nasıl meydana geldiği konusunda kesin yargılara varmak pek mümkün değildir. Aksine, bu kaygan zemini biraz daha anlaşılır kılmak adına farklı tanımlayıcı ve belirleyici kategoriler aracılığıyla duyguları daha detaylı tanımlama yoluna başvurulmuştur. Bu amaçla, öncelikle, yapılan çalışmalarda insanlarda birtakım duyguların diğerlerinden daha ön plana çıktığı öne sürülmüş ve bu duygular "birincil" (Plutchik, 1980, s. 8; Turner, 2007, s. 2), "temel” (Ekman, Sorenson ve Friesen, 1969, s. 87) veya "ana" (Thamm, 2006, s. 25) duygular olarak adlandırılmıştır. En basit tanımıyla, bu temel duygular, "duygusal kimyamızdaki 'atomlar' olarak kabul edil[ebilir]" (Solomon, 2002, s. 115). Evrimsel doğal seçilim sonucu bu duyguların biyolojik olarak insanlarda hâlihazırda var olduğu kanısı yaygınlaşmıştır. Bu duyguların sayısı farklı öneriler ve çalışmalar doğrultusunda artabilse de (Ekman, 1992, s. 550) birçok disiplinde temelde en 
az dört adet duygu bu grupta yer almaktadır. Birincil duygular, "insan nöroanatomisinde bulunan ve doğuştan olduğu düşünülen duygusal uyarılma durumlarını" ifade etmektedir (Turner, 2007, s. 2). Bu duyguların birçok varyasyonu çeşitli araştırmacılar tarafından önerilse de hemen hepsinde dört ana duygu ön plana çıkmaktadır: mutluluk, kızgınlık, üzüntü ve korku. $\mathrm{Bu}$ temel duygular, çeşitli yoğunlukta hissedilebildiği gibi bununla birlikte çeşitli şekillerde de ifade edilebilir. Yaşanan duyguların deneyimlendiği toplumsal ve kültürel bağlam çerçevesinde bu duyguları belirtmek ve aralarındaki ince farklılıkları belirginleştirmek için farklı ifadeler ve kelimeler de kullanılabilir. Bu tür "temel duygulardaki varyasyonlar için kullanılan dilsel etiketler, temel bir nörolojik kapasitenin dişavurumu" ve "altta yatan biyolojik altyapının üzerindeki bir çeşit duygusal üstyapı” olarak düşünülebilir (Turner, 2007, s. 3). Böylelikle, temel duyguları barındıran nörolojik ve/veya biyolojik altyapı, üstyapıdaki duygu farklılıklarını ve varyasyonlarını mümkün kılan bir zemin görevi görür. Dolasıyla, korku gibi temel bir duyguyu incelerken onun üzerine kurulu birtakım duyguları (endişe, kayg1, dehşet, vb.) ve onun varyasyonları ve farklı yoğunluktaki hissedilme seviyelerini de göz önünde bulundurabiliriz.

"Duygusal yaşamın temel ve indirgenemez bir birimi”" (Solomon, 2002, s. 115-116) olarak görülen birincil duygular arasında bulunan korku, en temel tanımıyla bir tehdit unsuru barındıran bir durum karşısında ortaya çıkan bir duygu olarak adlandırılmaktadır. Bu tehdit genellikle dışarıdan gelmektedir ve bedende belli başlı davranış ve/veya fizyolojik değişimlere (nefes alıp vermenin hızlanması, kalp atışının artması, damarların darlaşması, vb.) sebep olmaktadır. Dışsal tehdidin bedende meydana getirdiği bu tür değişikliklerin yarattığı his de korku olarak tanımlanmaktadır. Öte yandan, korku, evrimsel açıdan insanlar için elzem bir görev görmektedir. Örneğin, insan 1rkı korku duygusuna sahip olmasaydı muhtemelen çevresine uyum sağlayamayarak ve çevresel tehdit faktörlerini birer tehdit olarak algıla(ya)mayarak yok olurdu (Turner, 2007, s. 61). Bu nedenle, korku irrasyonel bir duygu durumu değil, belli değerlendirmeler ve kanılar doğrultusunda hissettiğimiz bir duygu olarak karşımıza çıkar. Temel duyguların bir parçası olarak korku, hem biyolojik/nörolojik bir altyapıya ve psiko-evrimsel bir gelişime (Plutchik, 1980, s. 9-15) sahip olarak görülür hem de sosyo-evrimsel açıdan sosyal ilişkiler çerçevesinde zaman içerisinde kültürel ve toplumsal olgular ile birlikte belli başı durumlar karşısında ortaya çıkan bir duygu olarak değerlendirilir (TenHouten, 1996, s. 196-200). Bu ikinci duruma baktığımızda, korkuyu sadece nöroanatomiye indirgeyemeyiz, aksine hemen bütün duygular gibi korku da bireyin içinden geldiği toplum ve kültür faktörleriyle birlikte bu duygunun yaşandığı ve/veya deneyimlendiği andaki durum ve olgular karşısında şekillenir. Robert Solomon'ın dediği gibi, “insanın 
korktuğu şey... ve duyguların nasıl ifade edilmesi gerektiği, topluma ve duruma bağlıdır" (Solomon, 2020, s. 119). Dolayisiyla, korku duygusunu tek bir zemine (biyolojik, nöroanatomik, toplum, vb.) veya nedene bağlamak doğru olmaz. Bunun aksine, korkunun oluşması ve deneyimlenmesinde bu faktörlerin aşağı yukarı her birinin etkisi olduğunu veya olabileceğini vurgulamak gerekir. Nitekim, duygular ile ilgili yapılan çalışmalarda mutabakat tam olarak sağlanamadığı gibi yakın zamanda sağlanabilecek gibi de durmamaktadır. $\mathrm{Bu}$ yüzden, duygular üzerine çalışan Jonathan Turner ve Robert Solomon gibi isimler, farklı disiplinlerden faydalanarak çok yönlü bir kuramsal zemin oluşturmayı hedeflemektedirler.

Yukarıda bahsi geçen farklı disiplinlerin yaklaşımları göz önüne alındığında görülmektedir ki korku duygusunun oluşumunda, biyolojik-nörolojik altyapıdan toplumsal olgulara geniş bir yelpazede birçok farklı faktör olduğu öne sürülmüştür. Ancak bu yaklaşımların çoğu korku duygusunu gerekli şartlar oluştuğunda bireyin bu şartlara verdiği tepki olarak değerlendirmektedir. Bu çalışmada ise, korkunun biyolojik yani insan doğası gereği mi yoksa sadece toplumsal olgulara ve dayatmalara indirgenebilir olup olmadığı gibi konuların aksine, korku duygusunu deneyimlemekte olan bireyin söz konusu duyguyu kendi perspektifinden nasıl deneyimlediği üzerinde durulacaktır. Bu amaçla, korku duygusunun birey tarafından zaman, mekân, beden ve öznelerarası boyutlarda nasıl hissedildiğini etraflıca tahlil etmek adına, bilincin işleyişini ve yapısını ele alan felsefe akımı fenomenolojiden yararlanılacaktır. Fenomenoloji, "birinci tekil şahıs tarafından deneyimlenen bilincin yapılarının incelenmesini”" ifade eder ve yaşantıları ve deneyimleri bilincin "yönelimselliği" olarak açıklar (D. W. Smith, 2013, par. 1). Bu özellik olmadan herhangi bir yaşantının/deneyimin mümkün olmadığını ileri sürer. Bir başka deyişle, bilincin en temel özelliği hâlihazırda bir şeye, nesneye (bir olay, bir obje, bir duygu, vb.) yönelmesidir ve bu yönelimselliği olmadan bilinç var olamaz. Fenomenoloji işte tam bu kesişme noktası üzerinde durarak yaşantının gerçekleştiği sırada algının nasıl şekillendiği, oluştuğu ve bireyin bu sırada onun dünyada varoluşunun altyapısını oluşturan zaman, mekân, beden ve öznelerarası düzlemlerde ne tür değişimleri deneyimlediğini gözler önüne sermesi açısından hem birinci tekil şahsı hem de onun dünyadaki olgulara yönelimini baz alır. Yönelim esnasındaki bilincin algısına yaptığı vurgu düşünüldüğünde, fenomenoloji, duygular bağlamında yukarıda bahsi geçen yaklaşımların üzerinde durmadığı bir noktaya 1şık tutmaktadır: Duyguların deneyimlendiği esnada bilincin bunları nasıl algıladığını ve onun dünya algısını (zaman, mekân, beden ve öznelerarası boyutlarda) nasıl etkilediğini ortaya koyması açısından duyguların değerlendirilmesinde farklı bir perspektif sunar. 
Yılmaz, H. (2021). Zaman, mekân, beden ve öznelerarası düzlemde sanatçının bir genç adam olarak korkusu. Humanitas, 9(18), 320-341.

Yirminci yüzyılın başında ortaya çıkan fenomenolojinin birinci şahsı, onun dünyaya yönelimini ve dünya algısını ele alması göz önüne alındığında, bu felsefi akım aynı dönemde ortaya çıkan modernist edebiyatla birçok benzerlik gösterir. Modernist eserlerde oldukça ön planda olan bilinç akışı, birinci şahıs bakış açısı, karakterlerin iç dünyası gibi olgular, fenomenolojinin sunduğu kavramsal araçlar sayesinde daha zengin bir okumaya elverişli hale gelir. $\mathrm{Bu}$ amaçla, bu çalışmada, korku duygusu ve onun birinci şahıs tarafından nasıl deneyimlendiği, İrlandalı yazar James Joyce'un Sanaţ̧ının Bir Genç Adam Olarak Portresi (1916) adlı modernist romanının başkahramanı Stephen'ın yaşadığı korkular aracılığıyla fenomenolojik açıdan irdelenecektir. Joyce'un romanında olduğu gibi diğer pek çok modernist romanda birinci şahıs ve bilinç akışı tekniği kullanılsa da çoğunda birden fazla karakter arası geçişler görülmekte ve farklı karakterlerin bilinç akışları arasında bir gidip gelme durumu söz konusu olduğundan bir nevi bölünme gerçekleşmektedir. Ancak romanın başlangıcından sonuna değin birinci şahıs ve tek kişinin (Stephen) bilinç akışı üzerinde durması sebebiyle Joyce'un romanı kesintisiz bir birinci şahıs perspektifi sunmaktadır. Üstelik, Joyce'un bu romanı, Stephen'ın yaşadığı korkularını ve bunları nasıl hissettiğini detaylı ve güçlü tasvirlerle vermesi itibariyle fenomenolojik çerçevede söz konusu korku duygusunu incelemek ve değerlendirmek için daha elverişli bir zemin sağlamaktadır. Böylelikle, bu çalışmada, korku yaşantısını etraflıca ele almak adına, zaman, mekân, beden ve öznelerarası düzlemlerinin korku duygusunun oluşumunda ne tür bir role sahip olduğu ve korkunun hissedilmesi esnasında bu düzlemlerin korku duygusuna kapılan birey tarafindan deneyimlenmesinde hangi değişimlere uğradığ fenomenolojik çerçevede tartışlacaktır.

\section{Zaman, Mekân, Beden ve Öznelerarası Düzlemin Fenomenolojik Süremi}

Korkunun nasıl deneyimlendiği üzerinde durmadan önce zaman, mekân, beden ve öznelerarasılık kavramlarına kısaca bakmak yerinde olacaktır çünkü bu kavramlar bireyin dünya ve çevresi ile ilgili nasıl konumlandığını ve bireyin varoluşunun en temelini oluşturan parçalardır. Bu kavramlar birbiriyle doğrudan ilintili olduğundan onları birbirinden ayrı düşünmemiz pek mümkün değildir çünkü bireyin yaşamı temelde bu kavramlar ekseninde vuku bulur. Söz gelimi, bir birey zaman-mekân süreminden ayrı düşünülemeyeceği gibi bedensiz ve başkaları olmadan da düşünülemez. Bu açıdan bakıldığında, varoluşu mümkün kılan bu kavramları birazdan ayrı ayrı ela alacak olmamıza rağmen onları bir bütünün ayrılmaz parçaları olarak düşünmemiz gerekir.

Zaman mefhumu, fenomenoloji geleneğinde bilincin yapıtaşlarından birini oluşturmaktadır. Bu felsefe akımının kurucusu kabul edilen Edmund Husserl'in zaman 
anlayışında, "içsel zaman bilinci” (Husserl, 2015, s. 13) her türlü algının ve yönelimselliğin temelini oluşturmaktadır. Hatta, "bilincin diğer tüm form ve yapılarında varsayılan en temel bilinç, zaman bilincidir” (Bernet, Kern ve Marbach, 1999, s. 101). Husserl'e göre zaman üç parçalı (geçmişe-yönelim, ilk-izlenim, geleceğe-yönelim) bir yapıya sahiptir: "Her algı, geçmişe-yönelimsel ve geleceğe-yönelimsel iç-avlusuna sahiptir” (Husserl, 2015, s. 134). Her bir anın algılanması veya algının gerçekleştiği her bir an (ilk izlenim, şimdi, şu an) aynı zamanda geçmişe ve geleceğe yönelimselliği de içinde barındırır. Bu durumun zorunlu olduğunu söylemek yanlış olmaz çünkü bu iki zıt kutuplara yönelim olmadan zaman bilinci gerçekleş(e)mez. Husserl, bu yapıyı açıklamak için melodi örneğini kullanır. En basit haliyle, bir melodi dinlediğimizde veya duyduğumuzda söz konusu melodide notaların ve ritimlerin (genellikle) birbirine uyumlu bir şekilde akıp gittiğini veya birbirini uyumlu bir şekilde takip ettiğini algılarız. Bu oldukça sıradan ve normal bir şeydir bizler için. Müziğin, melodinin, ritmin akışına bırakırız kendimizi. Husserl'in üç parçalı zaman yapısı işte tam olarak bu akışkanlığı mümkün kılmaktadır. Melodinin melodi olarak algılanabilmesi için ilk izlenimde algılanan nota bir sonraki anda geçmiş olacağından yeni gelen ilk izlenim aynı anda geçmişe yönelmek zorundadır veya bir başka deyişle geçmiş olan notayı şu anda kendinde (değiştirerek) barındırması ve tutması gerekmektedir. Öte yandan, aynı ilk izlenim geçmişe yönelirken eş zamanlı olarak geleceğe de yönelmiştir. Her an aynı zamanda bir sonraki anı da beklenti olarak içinde kapsamaktadır. Örneğe tekrar dönersek, bir yandan duyulan veya algılanan bir nota bir sonraki anda geçmiş olarak tutulurken, diğer yandan, bir sonraki notaya karşı da beklenti içerisindedir, bir sonraki notaya daha şimdiden hâlihazırda yönelmiştir. Böylelikle, melodinin akışı sağlanır ve melodi bir melodi olarak algılanabilir. Robert Sokolowski’nin belirttiği gibi, içsel zaman bilinci olmadan “akış deneyimimiz ayrık ve kesik olurdu... Sürekli akış hissi bizde hiç oluşmazdı... Biz ve deneyimlediğimiz şeyler, anlık parıltılar, anlık görünüşler, anlık maruz kalmalardan başka bir şey olmazdı” (Sokolowski, 2000, s. 135). Diğer bir deyişle, bu üç yapı her bir anda veya şimdide, deyim yerindeyse, iş başında olmasaydı her bir anı kesik ve parça parça algılardık ve bu yüzden de zaman akışı gerçekleşmezdi.

Zaman bilincinin yanı sıra, bir özne varoluşu itibariyle mekânsız yani dünyasız da düşünülemez. Bu yüzden, her ne kadar Husserl mekânın, öznenin kendisi tarafından ve daha sonrasında öznelerarası (birçok özne tarafından kolektif bir şekilde) oluşturulduğunu açıklamaya çalışsa da kendisinden sonra gelen Martin Heidegger, Jean-Paul Sartre ve Maurice Merleau-Ponty gibi filozoflar özneyi mekânın nasıl oluşturulduğundan/kurulduğundan ziyade öznenin içine "fırlatıldığı" bir yer olarak kabul etmiştir (Heidegger, 2018, s. 213). Maurice 
Merleau-Ponty'nin belirttiği gibi, “dünya... vazgeçilemez bir mevcudiyet olarak zaten oradadır" (Merleau-Ponty, 2017, s. 9). Bu açıdan mekânı incelerken, onun özne(ler) tarafından nasıl oluşturulduğu vurgusunun aksine onun nasıl deneyimlendiği ve yaşandığı üzerinde durmuşlardır. $\mathrm{Bu}$ konuda özellikle Heidegger'in “dünya-içinde-varolma" (Heidegger, 2018, s. 93) kavramı, Sartre ve Merleau-Ponty felsefesinde oldukça önemli bir yer tutar. Bu fillozoflar özneyi ele alırken onun dünyasız/mekânsız düşünülmesinin mümkün olmadığının altını çizmektedir. Varoluş ancak bir yerde, bir mekânda, yani dünyada varoluştur. Örneğin, Heidegger'in Dasein kavramı, kelimesi kelimesine "orada" (Da) ve "olma" (sein) sözcüklerinden oluşmaktadır. Bu açıdan, varoluş temeli itibariyle orada bir yerde var olmadır, yani dünyada var olmadır. Dünya-içinde-varolma fikri öznenin dünyada olmasının sanki bir nesnenin başka bir nesne içinde bulunmasına eşdeğermiş gibi düşünülmemelidir. Aksine, "var olmak hâlihazırda ve her zaman bir dünyaya sahip olmak... anlamına gelmektedir" (Clark, 2002, s. 18). Dünyada olan özne kaçınılmaz bir şekilde dünyanın anlamlar ağının içinde bulur kendini. Heidegger'in dünyanın "atıf tümlüğü” (Heidegger, 2018, s. 125) olarak tanımladığ 1 bu durum, dünyadaki her şeyin bir birine gönderimde ve atıflarda bulunmasını ifade etmektedir ve anlam bütünlügünü mümkün kılar. Özne, aslında dünyada "başkalarıyla, çevresiyle, araç ve gereçler... ile ilişkileri” (B. Smith ve Smith, 1995, s. 10) doğrultusunda var olmakla beraber her şeyin birbirine atıfta/gönderimde bulunduğu “'işleyen dünyanın’ içinde kaybolmuştur” (Guignon, 1993, s. 6). Örneğin, bir kurşun kalem gördüğümüzde onun nesnel özelliklerinden (uzun ince ve ucu sivri olan nesne) ziyade bizim için kullanılabilirliği (yazmaya yarayan nesne) ön plana çıkar. Gönderimselliği göz önüne alındığında bu kalem birçok farklı nesneye (kâğıt gibi) de referansı içinde barındırır. İşte tam olarak özne için mekân, her şeyin her şeye gönderimde bulunduğu bu tür atıf tümlügünü ifade etmektedir. Bu tabii ki sadece nesneler arasındaki atıfsallığı işaret etmez, aksine öznenin başkalarıyla ve çevresiyle (okul, iş yeri, vs.) olan ilişkilerini ve bu atıfsal ilişkiler doğrultusunda öznenin yapabileceği ve yapamayacağ 1 şeylere olanak verdiği kadar onları aynı zamanda sınırlandıran bir bütünlüğe de işaret eder. Mesela, öznenin öğretmen olabilmesi okulların, öğrencilerin ve daha kapsamlı düşünüldüğünde eğitim kurumunun var olmasına bağlı olmakla birlikte onun öğretmenliği ancak bu gönderimsellik bağlamında anlam kazanır. İçine firlatıldığımız dünya özneyi aslında dünyadaki atıflar ağının içine konumlandırır ve bu yüzden özne bu tümlüğü barındıran dünya olmadan var olamaz.

Zaman ve mekân gibi öznenin varoluşsal temellerinden bir diğeri de bedendir. Daha önce bahsettiğimiz zaman kavramında her ne kadar zaman bilinci diyerek sanki zihin/beden ikiliği sürdürülüyormuş izlenimi oluşsa da durum böyle değildir. Öznenin zaman algısı, 
bedenli bir varlık olarak bir mekânda yani dünyada yapabileceği veya yapamayacağı şeyler ile şekillenir ve anlam kazanır: yemek vakti, çalışma vakti, uyuma vakti, vb. Bu bağlamda, zaman-mekân düzleminde var olan özne temelde bedensel bir varlıktır. Heidegger beden üzerine neredeyse hiçbir şey söylememesine rağmen, onun yukarıda bahsi geçen dünyaiçinde-varolma fikri söz konusu varlığın zaten hâlihazırda bedensel bir varlık olduğuna işaret etmektedir. Fenomenoloji geleneğinde, Husserl yaşayan/deneyimlenen beden (Leib) ve nesne olarak beden (Körper) arasında bir ayrım yapar ve yaşayan bedenin dünya ile bilinç arasında bir köprü kurduğunu ileri sürer (Husserl, 1989, s. 169). Heidegger böyle bir ayrım üzerinde durmasa da kendisinden sonra gelen Sartre ve özellikle Merleau-Ponty bunun üzerine eğilmişlerdir. Sartre "kendi-için-varlık olarak beden" (le corps comme être-pour-soi) ve "başkası-için-beden" (le corps-pour-autrui) (Sartre, 2009, s. 405, 442) ayrımı yaparken Merleau-Ponty "nesne olarak beden" (le corps comme objet) ile "kişiye has beden" veya "kişinin kendi bedeni” (le corps propre) olarak ayırmıştır (Merleau-Ponty 2017, s. 115, 146, 212). Her iki düşünür de nihayetinde öznenin dünya ile ilişkisinin bedenden geçtiği fikrinde mutabıktır. Beden, öznenin dünyada varoluşunun veya dünyaya "yöneliminin sıfır noktası, buranın ve şimdinin hamilidir" (Husserl, 1989, s. 61). Öyle ki beden "tüm yaşantı[nın] daimî [ve] ezelî ufkudur" (Carman, 1999, s. 214). Bu bağlamda, beden, öznenin dünyadaki varlığının tüm olağanlığıyla akıp gitmesine olanak sağlamakla kalmaz günlük hayatını devam ettirmesinin temelini oluşturur. Bedensel olarak algıladığımız dünya veya bedenin de içinde bulunduğu alg1 alanı, bu söz konusu verilmiş mekânda/dünyada bedensel bir varlık olarak neler yapabileceğimizi, nasıl hareket edebileceğimizi veya daha geniş bir kapsamda ne tür olasılıklara sahip olduğumuzu da içinde barındırır.

İçinde bulunduğumuz dünyanın veya dünyada olmamızın bir diğer varoluşsal özelliği de öznelerarasılıktır. Bu kavram, Husserl ve Sartre'da başkalarının varlığı hakkındaki konuları irdelediklerinde ele aldıkları bir sorun olarak ortaya çıkar. Husserl, kariyerinin son dönemlerinde dünyanın kurulumunun tek bir bilinçten değil öznelerarası bir şekilde kurulduğunu/yapılandı(rıldı)ğını öne sürer (Kartal, 2015, s. 51). Öte yandan, Sartre ise içinde bulunduğumuz dünyada başkalarının varlığını "ontolojik zorunluluk" değil, hâlihazırda “olumsal zorunluluk” (Sartre, 2009, s. 340) olarak görür. Bu da başkalarının varlığının tamamen gelişigüzel olduğunu ve dünyanın veya öznenin öznelerarası bir altyapıya sahip olmadığını ileri sürer. Ancak, bu durum Heidegger ve Merleau-Ponty’de daha farklıdır. Bu iki isim için, dünya zaten her zaman öznelerarası bir dünyadır veya öznelerarasılıkla kuşanmıştır. Heidegger'in Dasein'ın varoluşsal yapısını açıklarken kullandığı önemli kavramlardan biri “birlikte-varolmadır” (Heidegger, 2018, s. 181). Bu kavram, en basit haliyle, "dünya-içinde- 
varolmanın komünel boyutu" olarak tanımlanabilir (Polt, 1999, s. 60). Birlikte-varolma, Dasein'ın başkalarıyla birlikte dünya-içinde-varolmasıdır. Heidegger'in dediği gibi, “[z]ira dünya-içinde-varolma açığa kavuşturulurken görülmüştür ki öncelikle dünyasız ne bir 'var' vardır, ne de salt özne verilidir. Ve sonuç itibariyle yalıtılmış bir ben de ötekiler olmadan verili değildir” (Heidegger, 2018, s. 185). Bu bağlamda, tıpkı öznenin dünyasız düşünülememesi gibi, özneyi diğer öznelerin var olmadığı bir bağlamda da düşünemeyiz çünkü atıflar tümlüğünün içerisinde, olanaklarını ve imkanlarını gerçekleştirmek adına öznenin attığı adımları benzer şekilde diğer özneler de gerçekleştirmektedir. Bir bakıma, “[d]ünya-içinde-varolmanın bu birliktesel zemini üzerinde dünya zaten hep başkalarıyla paylaştığım bir dünyadır. Dasein'ın dünyası birlikte-dünyadır. İçinde-olmak demek başkalarıyla birlikte-varolmak demektir" (Heidegger, 2018, s. 188). Özne, diğer öznelerle birlikte aynı dünyada var olmakla kalmaz aynı dünyadaki anlamlar bütünlüğü içerisinde benzer şekilde (benzer yönelimler, kaygılar, endişeler, vb.) var olur. Öznenin egzistansiyal olarak başkalarıyla birlikte-varolması dünyanın bir nevi “a priori öznelerarasılık” (Zahavi, 2001, s. 154) veya “özne-ötesi öznelerarasıl1k” (Coelho ve Figueiredo, 2003, s. 199) ile kuşandığını belirtmektedir. Heidegger’e göre, başkalarının varlığı daha çok yatıştırıcı, deyim yerindeyse hissizleştirici ve "sahih benlikten" (Heidegger, 2018, s. 204) mahrum bırakan bir etkiye sahip olsa da öznenin başkalarıyla karşılaşması özne için bir tür kendine dönüşü (kendi bedenselliğine, zaman ve mekânın farklı deneyimlenmesine) de tetikleyebilmektedir.

Yukarıda bahsettiğimiz dört ana parçadan oluşan bu düzlemler bütünlüğü -zaman, mekân, beden ve öznelerarasılık- öznenin varoluşunu mümkün kılan ve temellendiren en önemli yapıdır. Öznenin ancak bir dünyada önem ve anlam kazandığını göz önünde bulundurursak, söz konusu dünyada olma bu dört düzlemin bir arada bir zemin oluşturmasıyla mümkün hale gelebilmektedir. Dolayısıyla, her ne kadar öznenin bu düzlemlerdeki yaşantıları veya daha doğru bir tabirle bu düzlemleri deneyimlemesi, ayrı ayrı ele alınabilse de yaşantı düzeyinde bu dört farklı açı yekpare olarak düşünülmelidir. Örneğin, zaman, özne tarafından içinde bulunduğu duruma göre yavaş veya hızlı geçiyor olabilir veya öznenin bulunduğu mekân/çevre birtakım sebeplerden dolayı tehlikeli veya güvenli bir yer olarak deneyimlenebilir. Öte yandan, dünyanın akışına kendini kaptırmış bir bedenli özne, birden başkalarının yanında kendi bedenini bir nesne olarak deneyimleyebilir. Burada kısaca verdiğimiz örnekler, her bir düzlemin ayrı ayrı tanımlanabileceğini ve betimlenebileceğini ortaya koysa da daha yakından bakıldığında her biri aslında birbirine girifttir. Mesela, bedenin nesne olarak algılanması diğer üç düzlemi de içinde barındırmaktadır. Bedenin nesne olarak deneyimlenmesi anında öznenin zaman (günün şu veya bu saati) ve bulunduğu mekânın (okul, 
sokak, vb.) farkına varmasına sebep olur. Bu zaman-mekân süremi beraberinde, bu nesneleş(tiril)me genellikle başkalarının varlığıyla veya orada bulunmalarıyla gerçekleşmektedir. Böylelikle, her bir parça bir araya gelerek bu deneyimin veya durumun bütününü oluşturmaktadır.

$\mathrm{Bu}$ çalışmanın ikinci kısmında, İrlandalı modernist yazar James Joyce'un Sanatçının Bir Genç Adam Olarak Portresi adlı romanının başkahramanı Stephen Dedalus'ın korku duygusunu yukarıda anılan düzlemlerin her birinde nasıl deneyimlediği veya hissettiği üzerinde durulacak ve tartışılacaktır.

\section{Sanatçının Bir Genç Adam Olarak Korkusu}

Yirminci yüzyılın başlarında ortaya çıkan edebî modernizmde özne ve onun bilinci, yaşantısı ve bakış açısı oldukça ön plandadır. Karakterlerin içinde yaşadıkları dünyayı nasıl gördükleri, algıladıkları ve deneyimledikleri üzerinde duran modernist eserler bu yüzden öznenin dünyada varoluşunu her yönüyle ele alan fenomenolojik okumaya oldukça elverişlidir. Modernist akımın önde gelen isimlerinden James Joyce'un Sanatçının Bir Genç Adam Olarak Portresi adlı otobiyografik unsurlar taşıyan eseri, romanın başkahramanı Stephen Dedalus'ın bebeklikten erişkinliğe kadar olan dönemine odaklanarak onun büyürken geçtiği safhaları ortaya koyar. Sadece bununla da kalmayıp Stephen'ın bedensel ve zihinsel değişimlerini irdeleyerek onun erişkinliğe uzanan yolculuğunda hayata ve dünyaya bakışının nasıl şekillendiği üzerinde durur. $\mathrm{Bu}$ çalışmanın öncelediği korku duygusunun farklı düzlemlerde deneyimlenmesi konusu doğrultusunda, Stephen'ın korku (ve dehşet) duygusunu hissettiği iki farklı olay üzerinde durmak yerinde olacaktır. Bu bölümde, önce, Stephen'ın haksız yere Dolan Baba'dan gördüğü fiziksel şiddet esnasında yaşadığı korku duygusu ele alındıktan sonra, Stephen'ın roman boyunca hissettiği en güçlü duygu olan ve oldukça etkili tasviri yapılan üç gün süren inziva günlerinde yaşadığı korku incelenecektir. Özellikle bu ikinci örnekte, Stephen'ın din çerçevesinde günah, ölüm, mahşer günü ve cehennem gibi kavramlar karşısında nasıl korku yaşadığını gösteren durumlar üzerinde durularak onun bu korkuyu zaman, mekân, beden ve öznelerarası düzlemlerde nasıl hissettiği gösterilecektir.

Joyce'un romanında, Stephen'1n küçüklüğünden beri tüm algısı ve yaşantıları duyularıyla birlikte verilmektedir. Bir başka deyişle, yaşantıların ve olayların Stephen'da ne tür hisler uyandırdığı ve hangi duyularını tetiklediğini ön plana çıkarılmış şekilde sunulmaktadır. Örneğin, daha romanın ilk sayfasında şu gözlem kendine yer bulur: "Yatağını 1slatırsan önce sıcak olur sonra soğur" (Joyce, 2015, s. 51). Benzer şekilde, Clongowes okuluna gittiğinde Wells isimli bir okul arkadaşının kendisine omuz atması sonucu okulun 
foseptik çukuruna düşmesiyle ilgili olarak da anımsadığı şey yine bedensel duyular üzerinden verilmiştir: "Ne soğuk, ne yapışkandı su öyle!” (Joyce, 2015, s. 55). Duyularını oldukça güçlü deneyimleyen Stephen için korku duygusu da kuvvetli duyularla bezenmiş şekilde ortaya çıkar. Korkuyu ilk olarak yaşadığı bölüm, okulda etüt yönetmeni Dolan Baba'nın Arnall Baba tarafından yürütülen Latince dersini bir nevi teftiş amaçlı ziyaret etmesiyle başlar. "Tembel, haylaz yaramazları" (Joyce, 2015, s. 96) gözünden anladığını iddia eden Dolan, raketiyle Fleming isimli bir çocuğun eline altı defa vurduktan sonra öğrencileri derslerine dönmeleri hususunda azarlar. Dolan'ın daha ilk başta elinde raket ile sınıfa girmesi çocuklarda korku uyandırmıştır: "Bir anlık bir ölüm sessizliği, sonra raketin en sondaki sıraya çarpışının sesi. Stephen'ın korkudan yüreği hopladı" (Joyce, 2015, s. 95). Çocukların yüreğine böylesi bir korku salan Dolan, Stephen'a dönüp onun neden diğerleri gibi yazmadığını sorduğunda Stephen'in âdeta nutku tutulur: “'Benim... şeyim...' Korkusundan konuşamiyordu” (Joyce, 2015, s. 96). Bedensel bir varlık olarak dünyada olmamız dünyanın atıf tümlügü içerisinde rahat bir şekilde hareket etmemize olanak sağladığından korku karşısında bu dünyayla olan bağımız kopma noktasına gelebilir ve bu durum da söz konusu korku duygusunu bedensel ve mekânsal düzlemde oldukça güçlü hissetmemize sebep olur. Sartre'ın belirttiği üzere, bir duygu deneyimi esnasında dünya ile ilişkileri değișen şey bedenin ta kendisidir (Sartre, 1948, s. 61). Stephen da yaşadığı korku karşısında hem neredeyse konuşamaz hale gelir (sadece kekelemekle yetinir) hem de normal şartlarda oldukça rahat kullanabileceği yürüme ve görme kabiliyetleri bu durumdan etkilenir: "Stephen sınıfin ortasına sendeleyerek geldi, korkudan ve aceleden iyice körleşmişti... Korkudan bütün gövdesi... kolu... bütün organları acı ve korkuyla tit[riyordu]" (Joyce, 2015, s. 97). Bedensel olarak korkunun hissedilmesi Stephen'1n sadece konuşma yetisini bir anlık süreyle etkilemekle kalmaz aynı zamanda yürümesi ve görmesi de bu durumdan payını alır. Dolan Baba'nın onu çağırmasıyla korkudan âdeta kör olur ve tahtaya tökezleyerek çıkar. Tüm bedeni, kolu, eli ve hatta uzuvları korkuyla titrer. Beden düzeyinde yaşanan korku görmesine de etki ettiğinden mekân içerisindeki bedensel hareket uyumu da darbe yer ve bu sebeple ancak sendeleyerek veya tökezleyerek sınıfta hareket edebilir.

Öte yandan, anlatıcı, Stephen'ın bu olay karşısında duyduğu korkunun zaman boyutuyla ilgili bir bilgi vermese de Stephen'ın kekelemesi, sendeleyerek tahtaya çıkması ve titremesi gibi kısa süre içerisinde gerçekleşen olguları nispeten uzunca tasvir etmesi söz konusu kısa nesnel zamanın öznel olarak uzun hissedildiğine dair ipuçları da vermektedir. Üstelik, normalde öznenin dünyaya yönelmesinde geçmiş ve gelecek zaman belli bir eksen oluştururken, böylesi bir korku duygusu anında, geçmiş ve gelecek farkındalığ ortadan kaybolarak özne tüm benliğiyle şimdide bulur kendini. Bunun yanı sıra, Stephen'ın 
Yılmaz, H. (2021). Zaman, mekân, beden ve öznelerarası düzlemde sanatçının bir genç adam olarak korkusu. Humanitas, 9(18), 320-341.

korkusunun bir de öznelerarası boyutu olduğunun da altını çizmek yerinde olacaktır. Ders tüm olağanlığıyla akarken birden sınıfa Dolan Baba'nın girmesiyle tüm sınıfın atmosferi değişir: "Kapı sessizce açıldı ve kapandı. Sınıfta hızla bir fisııltı dolaştı: etüt yönetmeni. Bir anlık bir ölüm sessizliği... Stephen'ın korkudan yüreği hopladı" (Joyce, 2015, s. 95). Dolan Baba’nın dersleri teftiş etmesi çocuklar için bir korku kaynağı hâline gelmiş̧ir. Dolayısıyla, dünyaiçinde-varolmanın ifade ettiği öznenin kendini dünyanın akışına neredeyse şuursuzca bırakması aniden bir başka öznenin onun algısal alanına girmesiyle altüst olabilir. Bu durumda, Dolan Baba, bir nevi korku duygusunun Stephen'da tetiklenmesi hususunda bir katalizör görevi görmektedir. Bu açıdan bakıldığında, başkalarının özne üzerinde, daha doğrusu öznenin yaşantıları, hisleri ve duyguları üzerinde oldukça belirleyici etkiler yaratabildiği görülmektedir. Bu nedenle, Stephen'ın Clongowes'taki hayatından böylesi kısa bir kesit bile korku duygusunun farklı boyutlarda nasıl güçlü hissedildiğini göstermektedir.

Stephen'ın yukarıda bahsettiğimiz fiziksel şiddet ile ilgili erken dönem yaşantısının yanı sıra, onun korku duygusunu bahsi geçen dört düzlemde (zaman, mekân, beden ve öznelerarası) çok daha kuvvetli ve derinden hissettiği ikinci olay ise Stephen'ın ergenlik dönemine girmiş bir genç olarak Dublin'de bulunan Cizvit okulu Belvedere College'ta eğitim gördüğü dönemde inziva günleri sırasında yaşadığı korkuyla ilintilidir. Stephen'ın bu çekilme günlerinde yaşadığı korkunun boyutunu idrak edebilmek adına onun ergen bir genç olarak Belvedere College'ta nasıl bir öğrenci profili çizdiği üzerinde kısaca durmak doğru olacaktır. Clongowes'ta nispeten daha çekingen ve geride duran bir karakter olmasının aksine, Belvedere College'ta Stephen oldukça aktif bir öğrenci olarak (bir piyeste öğretmen rolünü üstlenir; yazdığı bir denemeyle para ödülü kazanır; bir topluluğun başına geçer) tasvir edilmektedir. Ancak, okulda gündüz çizdiği bu düzgün profilin bir diğer yüzü de vardır. Ergenliğe yeni giren her bir genç gibi, Stephen da daha önce kendisine yabancı olan birtakım bedensel arzular hissetmeye başlar ve bu arzuları doğrultusunda akşamları şehrin karanlık ve mülevves sokaklarında dolaşır ve ilk cinsel deneyimini de bu sokaklarda rastladığı bir hayat kadınıyla yaşar. Bu deneyim henüz on altı yaşında olan Stephen için bir dönüm noktası olur ve bundan sonra Stephen sıkça bu sokakları ziyaret eder ve kendini arzularının pençesinde bulur. Bedensel arzularına yenik düşen Stephen yaklaşı sekiz ay süren bir dizi günah işlemeye başlar. Stephen'ın Hristiyan inancına göre yedi ölümcül günahtan biri sayılan şehvet ile başlayan günahlar dizisi diğer günahları da doğurur ve Stephen oburluk ve açgözlülük gibi ölümcül günahları işlerken bulur kendini. Bu arka plan, Stephen'ın nasıl iki zıt kutupta veya uçlarda yol aldığını ve bununla birlikte bir tarafı mütedeyyin olmaya çalışan ama bir tarafıyla da günahkâr olan Stephen için iki arada bir derede kalmışlı̆̆ tasvir eder. Bir tarafta 
Stephen'ın bedensel açlığı, diğer tarafta ruhsal açlı̆̆ı varken, Stephen'ın bu iki boyuttaki açlığını aynı anda giderebilmesi pek mümkün gözükmemektedir çünkü beden ve ruh, dinsel inanışına göre, birbiriyle zıt bir ilişki içindedir. Bir başka ifadeyle, Stephen, bedensel arzularını ve şehvetini -ki bu sadece cinsel anlamda değil yeme içme ve açlığını giderme anlamında da düşünülmelidir- doyurmaya çalıştıkça ruhsal ve manevi tarafı zayıflamaktadır. Stephen, doğal olarak maneviyatının gitgide zayıfladığına ve artık iflah olamayacağına dair düşüncelere kapılır. İşte tam da bu arka plan göz önüne alındığında, Stephen'ın korku duygusunu zaman, mekân, beden ve öznelerarası düzlemde tüm benliğinde yaşaması ayrı bir anlam kazanmaktadır.

Belvedere College'ın koruyucusu Aziz Francis Xavier şerefine düzenlenen üç gün sürecek ve günah çıkarmayla son bulacak inziva günlerinde (Joyce, 2015, s. 159) Stephen'ın yaşadığı korku bedensel düzlemde çok etkili bir şekilde hissedilir. Bu çekilme günlerinde, birçok vaaz verilerek öğrencilerin dünyevi zevklerden ve arzulardan arınmaları telkin edilirken öte yandan günahlarından arınmayanların mahşer günü ve cehennemde ne gibi işkencelere maruz kalacakları üzerinde durulur. Rektör, inzivanın açılış konuşmasında dört şeyi -ölüm, yargılama, cehennem ve cennet- vurgular ve şöyle der:

Ve eğer, ki bu olabilir, bu anda şu önümdeki sıralarda Tanrı'nın kutsal inayetinden yoksun kalmak ve acı günahlar arasına düşmek gibi ağza alınmaz bir talihsizlik yükü altında kalmış herhangi bir zavallı varsa, yürekten inanır ve dilerim ki bu çekilme töreni o zavallının hayatında bir dönüm noktası olabilsin... Çıkarın atın zihninizden bütün dünyevi düşünceleri ve yalnız sondaki şeyleri düşünün, ölümü, yargılamayı, cehennem ve cenneti düşünün... Son şeyleri hatırlayan her zaman onları göz önünde tutarak hareket edecek ve düşünecektir. İyi bir hayat yaşayacak, iyi bir ölümle ölecektir... (Joyce, 2015, s. 163)

Daha ilk günden rektörün bu sözleri Stephen'a istemsiz ve hatta anlam veremediği bir şekilde dokunur. Bu konuşmadan sonra sessizce yürüyen arkadaşları arasında eve giderken "koyu bir sis zihnini sarmış gibiydi. Dağılmasını ve sakladığı bir şeyi ortaya çıkarmasını sersemlemiş bir halde bekledi" (Joyce, 2015, s. 163). Henüz anlamlandıramadığı bu "sis" zihnini kaplar ve onu sersemleştirir. O anda çok fazla bu sersemlemeye aldırış etmeden yemeğini iyi bir iştahla yedikten sonra birdenbire kendini "avını yedikten sonra ağzını yalayan hayvanının durumuna düşmüş" olarak görür (Joyce, 2015, s. 164). Bu iştah tabii ki o an ortaya çıkmış bir şey değildir, aksine şehvete yenik düşüp günah işlemeye başladığından itibaren gitgide artan ölümcül günahlara teslim olan Stephen, daha önce de lezzetli bir yemek düşlerken midesini doldurma arzusuyla yanıp tutuşmuştur: "Doldur içine hepsini diye öğüt veriyordu midesi ona" (Joyce, 2015, s. 153). Daha önce iştahla yemek yeme arzusunu yerine getirirken herhangi bir 
zihin bulanıklığı yaşamazken rektörün yukarıda alıntılanan konuşmasından sonraki yemek sahnesinde yine iştahla yese de derinlerde bir yerde bir sorun olduğunu sezer. Bu sorun, yavaş yavaş zihnine veya algısına sızmaya başlayan korkunun ilk sezildiği anı işaret eder:

Artık sona varmıştı; belli belirsiz bir korku pırıltısı zihnini saran sisi delmeye başladı... Ruhu yoğun bir yağın içine doğru yayılıyor ve orada donuyor, durgun korkusunun içinde ciddi olarak tehdit eden bir alacakaranlığın gittikçe daha derinlerine dalıyor, bu arada onun olan beden kayıtsız ve lekeli, kararmış gözlerden dışarıyı gözleyerek, çaresiz, rahatsız ve insan, ona bakacak öküzümsü Tanrı'nın önünde duruyordu. (Joyce, 2015, s. 164)

Zihnini saran sis beliren korkuyla birlikte aralanmaya başlar ve bedensel olarak lekelenmiş çaresiz bir insan olarak kendini Tanrı'nın önünde tüm çıplaklığıyla duruyormuş gibi hisseder.

İnzivanın ikinci günü ölüm ve yargılama ile ilgilidir ve Stephen'ın korkusu bu kavramlarla ilgili verilen vaazlarla birlikte dehşete dönüşür. Bu dehşet duygusu Stephen'ın tüm bedenini sarmakla kalmaz, Stephen onu bedeninin neredeyse her bir zerresinde duyumsar: "Ölüm soğukluğunun dış organlarına dokunuşunu ve yüreğine doğru sürünerek ilerleyişini duydu... son ter damlalarının derisinden dışarı sızışını, ölen organlarının güçsüzlüğünü, dilin tutuluşu, dolaşışı, cansız kalışını, yüreğin yavaşlayan, daha da yavaşlayan atışını...” (Joyce, 2015, s. 164). Böylece, Stephen ölüm anını düşündüğünde yaşadığı dehşet duygusu bedeninde yankı bulur ve daha önce dünyevi zevklerini bedeni aracılığıyla hissettiği, tattığ1 ve deneyimlediği gibi ölüme, yaklaştığı fikrine kapıldığında duyduğu dehşet tüm benliğini sararak bedeninde hisseder: “... boyun eğdiği bedeni ölüyordu. Mezara, bedeniyle... fırlatın onu toprakta bir uzun çukurun içine... çürüsün diye, sürünen kurtlar yığınını beslesin, seğirten şiş göbekli sıçanlar onu yesin bitirsin diye” (Joyce, 2015, s. 164-165). Ölüm ile yüzleşme fikri Stephen'1 doğrudan bedeninin ölümüne götürür ve bu sahnelerde Stephen, kendi bedeninin çürüdüğünü, parçalandığını ve fareler tarafından yendiğini görür. Üstelik, sadece ölüm değil, öldükten sonra yargılama günüyle ilgili verilen vaazda da yargılama gününde günahkârların yaptıkları iyilikler dışında kimseden yardım alamayacakları ve o gün Tanrı'nın hiçbir şekilde merhamet göstermeyeceği belirtildiğinde, Stephen şöyle hisseder: "Vaizin bıçağı açığa vurulmuş vicdanının derinliklerine girmişti ve şimdi ruhunun günahlarla çürüdüğünü duyuyordu” (Joyce, 2015, s. 167-168). Vaizin ağzından çıkan her bir kelimeyi, Stephen bedenine saplanan bir bıçak darbesi gibi hisseder.

Benzer bir şekilde, inzivanın üçüncü gününde cehennem üzerine verilen vaazda cehennem tasvirleri, âdeta Stephen'1n zihnine işler ve onu derinden etkiler. Söz konusu vaazda cehennem ateşi ile ilgili detaylı betimlemeler verildiğinde, Stephen dehşeti bedeninde 
hisseder: "Ateşin aç alevlerinin üzerine doğru geldiğini duyan eti çekildi, çevresinde boğucu havanın girdabını duyarak kurudu... Bir ateş dalgası gövdesini yalayıp geçti: birincisi. Gene bir dalga. Beyni yanmaya başladı... Kafatasının çatırdayan barınağında beyni kaynıyordu” (Joyce, 2015, s. 178-179). Stephen, günahları için ödenmesi gereken bedeli bedeninde hissederek cehennem için bir tür ön izleme deneyimler ve bu bedensel deneyim başlı başına Stephen'ın yaşadığı ölüm, yargılama ve cehennem kavramları karşısında hissettiği dehşet duygusundan doğmuştur. Böylece, Stephen'1n yaşadığı korku duygusu ve verilen örnekler göz önüne alındığında, korku gibi temel duyguların en önemli boyutlarından biri büyük ölçüde bedenseldir. Burada vurgulanan fikir söz konusu duyguların yalnızca bedensel olarak hissedilmesi değil, korku duygusunun beden aracılı̆̆ıyla meydana gel(ebil)diğidir. Yukarıda verilen hemen tüm örneklerde, Stephen korkuyu ancak bedeniyle duyumsayabilmektedir. Hatta Stephen'ın aklına gelen korkutucu bir fikir veya düşünce dahi yine beden düzleminde verilir: Günah çıkarma “[d]üşünce[si], yumuşak etinin içinde soğuk parlak bir kılıç gibi kaydı" (Joyce, 2015, s. 180).

Yukarıda örneklenen ve beden düzleminde incelenen korku ve dehşet duyguları eş zamanlı olarak Stephen'ın mekânla olan bağını da etkiler ve Stephen'ın mekânsal düzlemde oryantasyonunu yitirmesine sebep olur. Öznenin mekânsal algısının dünyaya olan bedensel yönelimiyle iç içe olmasından ötürü, bedenimizle olan bütünlüğümüz belli bir mekânda, daha geneliyle dünyada rahatça hareket etmemizi sağlar. Heidegger'in dünya-içinde-varolma fikrini hatırlarsak, hâlihazırda bedensel olarak var olma beraberinde bir yerde (dünyada) bulunduğumuzu vurgular. Dolayısıyla, korkunun Stephen'ın bedeninde yarattığı yaşantılar benzer şekilde onun mekân algısını da etkiler. Vaazların kendisinde yarattığı korku duygusuyla birlikte Stephen mekâna tutunamaz hale gelir:

Bacakları birbirine çarparak, kafasındaki deri, bir hortlağın eli değmiş gibi titreyerek kilisenin ortasındaki geçitten yürüdü... Her adımında şimdiden ölmüş olmasından, kılıf olan bedeninden ruhunun koparılıp alınmasından, uzay içinde tepetaklak aşağılara doğru uçmaktan korkuyordu. Ayaklarıyla zemini kavrayamadı ve sırasına düşer gibi oturdu... (Joyce, 2015, s. 178)

Tıpkı dayak sahnesinde Dolan Baba'nın karşısında sendelemesi ve korkudan körleşmesi gibi, bu son vaazın akabinde bacakları tutmaz hale gelir ve zemini kavrayamayarak sırasına ancak düşercesine oturabilir. Vaazlar, diğer öğrencilerin aksine, Stephen'ın öncesinde kendini kaptırdığı günahların etkisiyle onu sersemletmekle kalmaz, mekânsal farkındalığına da darbe vurur. Söz konusu farkındalığı kaybeden Stephen -soydaşı Dedalus'ın oğlu İkarus gibi- uzay boşluğunda tepetaklak bir serbest düşüş yaşayacağını zanneder. Vaazların onda uyandırdığı dehşet duygusu sonucu gerçek mekândan kopmasıyla bir nevi bu serbest düşüşü gerçekten 
yaşar: "Kafasından bir taç gibi alevler fışkırdı sesleri andıran çığlıklarla: -Cehennem! Cehennem! Cehennem! Cehennem! Cehennem!” (Joyce, 2015, s. 178-179). Cehennemi tasavvur eden ve dehşete kapılan Stephen, gaipten sesler duymaya başlar ve bu sesler tekrar tekrar cehennem kelimesini andırmakta ve yinelemektedir. Böylelikle, Stephen, gerçek dünyadan kopar ve kendini cehennem ateşinde yanıyormuş gibi hisseder. Kafatasının çatladığ 1 , beyninin yandığg ve kabarcıklandığı izlenimine kapılır (Joyce, 2015, s. 178-179).

Stephen, cehennemde olma hissini yaşadığı anlarda hâlbuki sınıfta oturmaktadır. Stephen mekândan kopup başka âleme daldığında, sınıfta arkadaşları vaaz ile ilgili konuşmakta ve vaazın onların nasıl ödünü kopardığını tartışmaktadırlar. Anlatıcının belirttiği üzere, Stephen "[g]üçsüzce arkasına yaslandı sırada. Ölmemişti. Tanrı gene bağışlamıştı onu. Hâlâ bildiği okul dünyasındaydı. Mr Tate ile Vincent Heron pencerenin yanında duruyor, konuşuyor, şakalaşıyor, dışarıdaki kasvetli yağmura bakıyor, başlarını kımıldatıyorlardı" (Joyce, 2015, s. 179). Stephen mekânsal farkındalığını geri kazandığında görüyor ki cehennemde ateşler içinde değil, aksine oldukça olağan ve alışık olduğu sınıfındadır. Onu şaşırtan bir şekilde, her şey tüm alışılagelmişliğiyle devam etmektedir: "O kadar iyi tanıdığı sesler, gündelik kelimeler, sesler durup da öbür çocuklar durgun durgun yemeklerini çiğnerken ve sessizlik ağır ağır geviş getiren sığırların sesleriyle dolarken sınıftaki dinginlik, yanan ruhunu huzura kavuşturdu" (Joyce, 2015, s. 179). Stephen, ancak kendine geldiğinde tekrardan konumsal oryantasyonunu geri kazanır ve dünyada olmasının barındırdığı ve sağladığı mekânsal yönelimselliğine tekrar kavuşur. Benzer bir şekilde, günah çıkarmak üzere okuldan uzakta bir kiliseye gitmek için sokaklarda yürürken mekânla olan bağı kopar ve ancak belli bir süre sonra sokaktaki oryantasyonunu geri kazanır: "Bulunduğu yerin bilinçliliği yükselip alçalarak geri döndü ona ağır ağır... yaşanmamış ulu bir zaman süresi üzerinden. Çirkin manzara kendini bileştirdi çevresinde; gündelik sesler, dükkânlarda yanan gaz alevi, balık, içki, ıslak talaş kokusu...” (Joyce, 2015, s. 196). Bahsi geçen örnekler göstermektedir ki bedensel düzlemin yanı sıra korku ve dehşet duyguları mekânsal düzlemde de oldukça yoğun hissedildiğinden öznenin mekân oryantasyonunu derinden sarsar böylece özneyi zaafa da uğratabilir.

Beden ve mekân düzlemlerinin yanı sıra incelenmesi gereken bir diğer düzlem, korkunun zaman mefhumu ve bilincine etkisidir. Korku duygusunun deneyimlenmesi esnasında öznenin zaman algısı değişir, geçmiş ve gelecek geri plana çekilir ve özne şimdiye kitlenir. Bedensel olarak mekânla (dünyayla) uyum içerisinde olduğu vakitlerde, zaman Stephen için olağan akmaktadır. Geçmişe ve geleceğe yönelimler zaman bilincinde akışı 
sağladığı gibi algının gerçekleşmesini de mümkün kılar. Her iki zaman kutbuna (geçmiş ve gelecek) yönelmeyi düşündügüüüzde aslında bu yönelimin tüm hayatımızı da düzenlediğini görmek mümkündür. Zamanın deneyimlenmesi geneli itibariyle yaptığımız veya yapacağımız şeylerle vuku bulur. Örneğin, inziva günlerinden önce, Stephen, okulda önce akşam yemeğinde verilecek yemeğin hayalini, ardından akşam sokaklarda hangi hayat kadınlarıyla karşılaşacağının hayalini kurar ve bu iki örnek, zamanı, yapmayı düşlediği şeylerle deneyimlediğini gösterir:

[Stephen] okul odası penceresinin sıkıcı dört köşeliğinden dışarı bakarken midesinin yemek istediğini duydu. Akşam yemeğinde etli türlü olacağını umdu; koyu, biberli, unla koyultulmuş salçanın içine kepçeyle boşaltılacak şalgamlar... Karanlık gizli bir gece olacaktı. Erkenden gece karanlığı çöktükten sonra genelevler mahallesinin orasını burasını sarı lambalar aydınlatacaktı. Sokaklarda dolambaçlı bir yol izleyecek, korku ve sevinç titreşimleri arasında gittikçe daha çok yaklaşacak, sonunda ayakları onu ansızın bir köşeden döndürüverecekti... Kendi iradesinin ansızın kıpırdanışını ya da onların yumuşak, kokulu etlerinden günaha düşkün ruhuna ansızın gelecek bir çağrıyı bekleyerek dingin adımlarla yanlarından geçecekti. (Joyce, 2015, s. 153-154).

Stephen'ın geçmiş ve geleceğe şimdiki andan yönelmesi hâlihazırda zaman bilincinin içinde taşıdığı olağan bir durumdur. Ancak, korku esnasında bu yönelimler ya minimuma iner ya da neredeyse tamamen ortadan kalkar. Sartre'ın altını çizdiği gibi, korku sadece korkuyu tetikleyen şeyin şu andaki korkunçluğu değildir, aksine korku durumu "tüm geleceğin üzerinde yayılır ve onu karartır" (Sartre, 1948, s. 81). Bu durumda, Stephen'ın vaazlar sırasında hissettiği ölüm, hesaplaşma günü ve cehennem korkusu tam olarak onun zaman mefhumuna darbe indirir: "Ve o gün gelir, gelecektir, gelmelidir: ölüm günü, yargılanma günü. Ölmek, öldükten sonra da yargılanmak insana vergidir. Ölüm kesindir... Kesin olmayan ne zaman ve nasıl ölüneceği... Tanrı'nın Oğlu sizin O’nu beklemediğiniz bir anda gelir” (Joyce, 2015, s. 167). Bu korku Stephen'ın her bir zerresini sararak onda zamanının bittiği ve zamanın sonuna geldiği izlenimi yaratır. Daha inziva günleri başlamadan önce zihni ve düşünceleri bir geçmişe bir geleceğe tüm olağanlığıyla gidip gelirken, şimdi Stephen zamanın kendisi için son bulduğunu ve tükendiğini düşünür: "Tanrı her şeye kâdirdi. Tanrı onu şimdi çağırabilirdi, sırasında otururken çağırabilirdi, çağrıldığının bilincine bile varamadan. Tanrı çağırmıştı. Evet. Ne? Evet... Ölmüş̧ü. Evet. Yargılanmıştı” (Joyce, 2015, s. 178). Stephen yaşadığı korkuyla zamana âdeta tutunamaz hale gelir ve onun için artık geçmişi telafi edebileceği ve günahlarının kefaretini ödeyebileceği bir geleceği tahayyül edemez. Geçmiş ve gelecek ortadan kalkar, sadece ölümün, yargılanmanın ve cehenneme savruluşun gerçekleştiği 
şimdi vardır. Bu düzeyde yaşadığı korku duygusuna kadar zaman onun yapabileceği şeyler konusunda tüm olasılıkları önüne sererken şimdi tüm bu olasılıkları tek bir hamleyle yok eder. Zaman artık kalmamıştır, hatta yoktur ve bu nedenle dehşet duygusu esnasında her şey için çok geç kalındığına dair bir zaman deneyimi bile mümkün gözükmez. Ancak hissettiği korku yavaş yavaş yerini dinginliğe bıraktığında zaman mefhumu geri gelir:

Hâlâ zaman vardı... Ruhu gittikçe pişmanlıktan gelme huzurun derinliklerine çöktü, artık korku acısı çekemiyor, derinlere çökerken bir küçük dua gönderiyordu. Evet, evet, daha hâlâ kurtulabilirdi; yürekten pişmanlık getirecek ve bağışlanacaktı; o zaman yukarıdakiler, cennettekiler, geçmişi örtmek için onun neler yapabileceğini göreceklerdi. Bütün bir hayat, hayatının her saati. Sadece biraz beklemeli. (Joyce, 2015, s. 179-180)

Görüldüğü üzere, korku yerini sakinliğe bıraktığında, zaman, inziva günlerinden önce Stephen'a sağladığı tüm olasılıklarıyla birlikte geri döner. Stephen, geleceğe, yaşadığı korkuyu ve dehşeti bir daha yaşamamak adına yapacağ 1 ve itinayla yerine getireceği tüm dini pratikler ışığında yönelir. Bir diğer ifadeyle, korku duygusunun ortadan kalkmasıyla, zaman, Stephen'a tekrardan kendini kurtarma ve arınma olasılığını verir.

İnziva günlerinin ve vaazların Stephen'da uyandırdığı korku duygusu ile ilgili olarak ele alacağımız son düzlem öznelerarasılıktır. Clongowes’taki fiziksel şiddet sahnesinde olduğu gibi, bu çekilme günlerinde de korkunun öznelerarası boyutta meydana geldiğini ve deneyimlendiğini söylemek yanlış olmaz. İnziva günlerinde Stephen'ın korku duygusunu yaşamasında, Clongowes’ta Dolan Baba'nın gördüğü görevi, başka özneler üstlenir. Öncelikle açılış konuşmasında rektörün ölüm, yargılama, cehennem ve cennet üzerinde durması ve öğrencilerin bunları hiçbir zaman akıllarından çıkarmamaları gerektiğini salık vermesi, Stephen'ın zihnini bir sisin sarmasına sebep olur (Joyce, 2015, s. 163). Aynı şekilde, diğer vaazlarda verilen detaylı ve duyumsal tasvirler yine Stephen'da dehşet uyandırır. Normal şartlarda tekrar tekrar günah işlerken bunların farkına var(a)mayan ve böylelikle bu konuları belki de zihninin karanlık köşelerine iten Stephen, bu üç günlük inzivada ancak başkaları (rektör, vaizler, rahipler) aracılığıyla bu farkındalığa varır. Söz konusu başkalarının ağzından çıkan her bir kelimeyi âdeta kendine yöneltilmiş hissettiğinden Stephen'da korku duygusu belirir: "Her kelime onaydı. Tanrı'nın bütün gazabı onun iğrenç ve gizli günahına yönelmişti” ve "Her kelimesi onun içindi. Doğruydu. Tanrı her şeye kâdirdi” (Joyce, 2015, s. 167-168, 178). Bu açıdan bakıldığında, kullanılan her bir kelime ve geneli itibariyle dil, hâlihazırda bir özneye bireysel olarak ait bir araçtan ziyade öznelerarası bir oluşum ve başkalarıyla gerçekleşen/gerçekleştirilen bir eylemdir. Vaizin ağzından çıkan her bir kelimeye bir nevi kodaçılımlama yapan Stephen'ın korkusu başka özneler aracılığıyla, yani öznelerarası 
düzlemde, vuku bulur. Bir başka örnek de Stephen'ın gerçekten arınabilmesi için günah çıkarması gerektiğinin farkına varmasıdır. Günah çıkarma maksadıyla günahlarını bir rahibe anlatması gerektiğini düşündükçe korkusu gitgide artar çünkü günah çıkarma sadece günahlardan arınmak için günahları itiraf etme olarak algılanmamalıdır. Aksine, günah çıkarmanın en önemli bileşeni günahların bir başka özneye itiraf edilmesidir: "İtiraf et! İtiraf et! Vicdanı bir gözyaşı ve bir duayla yatıştırmak yetmezdi. Kutsal ruhun vekili önünde diz çökmeli, saklı günahlarını dosdoğru ve tövbe ederek anlatmalıydı” (Joyce, 2015, s. 194). Günahlarını başka bir özneye itiraf etmesi gerektiğinin farkına varan Stephen, bunu başta "basit bir iş" olarak görse de kısa süre içerisinde durumun vahametini ve ciddiyetini idrak eder: “... o zaman açıkça anladı ki kendi ruhu, isteyerek, düşünceyle, sözle, eylemle, kendi bedeni yoluyla günah işlemişti. İtiraf et! Her günahını itiraf etmesi gerekiyordu. Yaptıklarını nasıl anlatırdı papaza? Anlatmalı, anlatmalı. Ya da nasıl anlatırdı utancından ölmeden?" (Joyce, 2015, s. 194-195). Stephen'ın korkusu, kaçınılmaz bir şekilde öznelerarası boyutta bulunan günah çıkarma eylemiyle birlikte daha da artar çünkü nihayetinde söz konusu din görevlileri hem kendileri öznedir hem de kendilerini aşan bir öznenin (Tanrı) vekilleridir. Dolayısıyla, Stephen'ın kendini Tanrı'nın gözünde günahkâr görmesi, bu özneden (Tanrı) korkması ve kendini arındırmaya çalışması da onun Tanrı'yla arasındaki öznelararası boyutun bir parçasıdır.

\section{Sonuç}

$\mathrm{Bu}$ çalışmada, insanlar ve hemen tüm türler için en temel ve evrensel duygular arasında gösterilen korku duygusu, beden, mekân, zaman ve öznelerarası düzlemleri içeren dört farklı boyutta ele alınmıştır. Üstelik, korku duygusu ve benzerlerinin nasıl meydana geldiğinden ziyade, korkunun hissedilen bir duygu durumu olarak öznenin kendi bedeni, zaman algısı, mekânla ilişkisi ve başkaları ile bağlarını nasıl etkilediği ve bu olağan kavramların özne için nasıl yeni anlamlar ve farklı yaşantılar doğurduğu üzerinde durulmuştur. Ayrıca, bu düzlemlerde var olan öznenin deneyimlediği korku duygusunu örneklemek adına James Joyce'un Sanatçının Bir Genç Adam Olarak Portresi adlı romanın başkahramanı Stephen'ın bizzat yaşadığı iki olay (fiziksel şiddet ve inziva günleri) derinlemesine incelenmiş ve Stephen'ın hissettiği korku ve dehşet duygularının soyut olmaktan çok ötede yani oldukça somut olduğu ve eş zamanlı olarak onun beden, zaman, mekân ve öznelerarası algısını nasıl değiştirdiği ve etkilediği gösterilmiştir. Bununla birlikte, korku duygu durumunun gerçekleşmesiyle birlikte, öznenin bahsi geçen düzlemlerde nasıl derinden etkilendiği ortaya konmuştur. Böylece, korku gibi duyguların, aslında bu 
Yılmaz, H. (2021). Zaman, mekân, beden ve öznelerarası düzlemde sanatçının bir genç adam olarak korkusu. Humanitas, 9(18), 320-341.

düzlemlerin özneye sağladığı akışın aksamasında açı̆̆a çıktığı ve baş gösterdiği vurgulanmıştır.

En temel duygulardan bir tanesi olarak kabul edilen korku duygusunu fenomenolojik bağlamda tahlil eden bu çalışma, biyolojik/nörolojik, sosyolojik, bilişsel ve psiko-evrimsel gibi yaklaşımların tek yönlü incelemelerinin ötesine geçerek bu tür duyguların daha kapsamlı ele alınması gerekliliğini vurgulamıştır. Üstelik, söz konusu yaklaşımların duyguları belli olgulara indirgemesini bertaraf ederek bu duyguların özne tarafından algılanışı ve deneyimlenmesi gibi konuların her türlü duygunun değerlendirilmesinde oldukça zengin ve çok yönlü bir perspektif sunduğunun da altını çizmiştir. Bu durum, daha önce bahsi geçen Thamm ve Turner gibi araştırmacıların duygu araştırmaları konusunda farklı yöntemlerin kuramsal verimlilik getireceği yönündeki çoğulcu çabalarına da bir katkı sağlayacaktır. Özellikle, yapılan çalışmaların son derece öznel olan duyguları olabildiğince nesnel değerlendirme çabalarına ve bu çabaların indirgeyici tutumu karşısında, fenomenolojik değerlendirme, öznel olguların zenginliğini ortaya koyması açısından bu çalışmalar için oldukça verimli bir bakış açısı temin edecektir. Ayrıca, Joyce gibi modernist yazarların anlatılarının öznel yaşantılara ve duygulara tüm detaylarıyla anbean odaklanması da duyguların derinliğini edebiyattaki yansımasını kavramak adına oldukça elverişli bir zemin sunmaktadir. 
Yılmaz, H. (2021). Zaman, mekân, beden ve öznelerarası düzlemde sanatçının bir genç adam olarak korkusu. Humanitas, 9(18), 320-341.

\section{Kaynakça}

Bernet, R., Kern, I., ve Marbach, E. (1999). An introduction to Husserlian phenomenology. Evanston: Northwestern University Press.

Carman, T. (1999). The body in Husserl and Merleau-Ponty. Philosophical Topics, 27(2), 205-226.

Clark, T. (2002). Martin Heidegger. London: Routledge.

Coelho, N. E. ve Figueiredo, L. C. (2003). Patterns of intersubjectivity in the constitution of subjectivity: Dimensions of otherness. Culture and Psychology, 9(3), 193-208.

Ekman, P. (1992). Are there basic emotions?. Psychological Review, 27(3), 550-553.

Ekman, P., Sorenson, E. R., ve Friesen, W. V. (1969). Pan-cultural elements in facial displays of emotions. Science, 164, 86-88.

Emotion. (t.b.). American psychological association dictionary of psychology içinde. https://dictionary.apa.org/emotion

Guignon, C. (1993). Introduction. C. Guignon (Ed.), The Cambridge companion to Heidegger içinde (s. 1-41). Cambridge: Cambridge University Press.

Heidegger, M. (2018). Varlık ve zaman (K. Ökten, Çev.). İstanbul: Alfa. (Orijinal çalışma basım tarihi 1927)

Husserl, E. (1989). Ideas pertaining to a pure phenomenology and to a phenomenological philosophy: Studies in the phenomenology of constitution II (R. Rojcewicz ve A. Schuwer, Çev.). Dordrecht: Kluwer Academic Publishers. (Orijinal çalışma basım tarihi 1952)

Husserl, E. (2015). İçsel zaman bilincinin fenomenolojisi üzerine (M. Keskin, Çev.). İstanbul: Avesta. (Orijinal çalışma basım tarihi 1928)

Joyce, J. (2015). Sanatçının bir genç adam olarak portresi (M. Belge, Çev.). İstanbul: İletişim. (Orijinal çalışma basım tarihi 1916)

Kartal, O. (2015). Fenomenolojiden politikaya 20. yüzyılda başkalık sorunu (Yayımlanmamış doktora tezi). Hacettepe Üniversitesi, Ankara.

Merleau-Ponty, M. (2017). Algının fenomenolojisi (E. Sarıkartal ve E. Hacımuratoğlu, Çev.). İstanbul: İthaki. (Orijinal çalışma basım tarihi 1945) 
Yılmaz, H. (2021). Zaman, mekân, beden ve öznelerarası düzlemde sanatçının bir genç adam olarak korkusu. Humanitas, 9(18), 320-341.

Plutchik, R. (1980). A general psychoevolutionary theory of emotion. R. Plutchik ve H. Kellerman (Ed.), Emotion: Theory, research, and experience Cilt 1 içinde (s. 3-33). Cambridge, Massachusetts: Academic Press, Inc.

Polt, R. (1999). Heidegger: An introduction. London: UCL Press.

Sartre, J.-P. (1948). The emotions: Outline of a theory (B. Frechtman, Çev.). New York: Philosophical Library. (Orijinal çalışma basım tarihi 1939)

Sartre, J.-P. (2009). Varlık ve hiçlik: Fenomenolojik ontoloji denemesi (T. Ilgaz ve G. Çankaya Eksen, Çev.). İstanbul: İthaki. (Orijinal çalışma basım tarihi 1943)

Smith, B. ve Smith, D. W. (1995). Introduction. B. Smith ve D. W. Smith (Ed.), The Cambridge companion to Husserl içinde (s. 1-44). Cambridge: Cambridge University Press.

Smith, D. W. (2013). Phenomenology. The Stanford Encyclopedia of Philosophy içinde. https://plato.stanford.edu/archives/sum2018/entries/phenomenology/

Sokolowski, R. (2000). Introduction to phenomenology. Cambridge: Cambridge University Press.

Solomon, R. C. (2002). Back to basics: On the very idea of "basic emotions." Journal for the Theory of Social Behaviour, 32(2), 115-144.

TenHouten, W. D. (1996). Outline of a socioevolutionary theory of the emotions. International Journal of Sociology and Social Policy, 16(9-10), 190-208.

Thamm, R. A. (2006). The classification of emotions. J. E. Stets ve J. H. Turner (Ed.), Handbook of the sociology of emotions içinde (s. 11-37). New York: Springer.

Turner, J. H. (2000). On the origins of human emotions: A sociological inquiry into the evolution of human affect. Stanford: Stanford University Press.

Zahavi, D. (2001). Beyond empathy: Phenomenological approaches to intersubjectivity. Journal of Consciousness Studies, 8(5-7), 151-167. 